\title{
Idiopathic giant cell myocarditis in a newborn: case report
}

\author{
Doğuş Özdemir-Kara ${ }^{1}$, Sultan Pehlivan ${ }^{1}$, Dilhan Türkkan ${ }^{1}$, Hanife Alkan-Alkurt ${ }^{2}$, \\ Barış Akduman ${ }^{2}$, Mustafa Karapirli ${ }^{2}$ \\ ${ }^{1}$ Department of Pathology, ${ }^{2}$ Ankara Branch of the Council of Forensic Medicine, Ankara, Turkey. \\ Email:dogusdr@yahoo.com \\ Received: 24th August 2015, Revised: 22nd February 2016, Accepted: 1st March 2016
}

\begin{abstract}
SUMMARY: Özdemir-Kara D, Pehlivan S, Türkkan D, Alkan-Alkurt H, Akduman B, Karapirli M. Idiopathic giant cell myocarditis in a newborn. Turk J Pediatr 2016; 58: 429-431.

Idiopathic giant cell myocarditis (IGCM) is a rare cause of arrhythmia, heart failure and death in children. The etiology of IGCM is unknown. Endomyocardial biopsy and histological examination are essential for diagnosis. In our case, a one-month-old baby boy with no prior medical history died during breastfeeding. The gross autopsy and drug screen failed to disclose a cause of death. Hemotoxylen Eosin (H\&E) stained cardiac tissue slides showed widespread and multifocal necrosis accompanied by mixed inflammatory infiltrate. Admixed with the infiltrate were fibroblastic proliferation and multinucleated giant cells in the absence of sarcoid like granuloma. Although myocarditis is usually thought to be a disease of older children, infants can also be affected. This entity can be the cause of some cases of sudden unexpected death in infancy.
\end{abstract}

Key words: myocarditis, newborn.

Myocarditis is clinically and pathologically defined as 'inflammation of myocardium.' Although this definition sounds straightforward, the diagnosis and treatment of myocarditis have been controversial ${ }^{1}$. The Dallas pathological criteria published in 1986, presented the initial effort to develop standardized diagnostic guidelines for histopathological classification of myocarditis. This attempt to create reproducible histopathologic criteria, made it possible to discriminate myocarditis from ischemic necrosis and other conditions. By this definition, active myocarditis is characterized by an inflammatory cellular infiltrate accompanied by myocyte necrosis, whereas borderline myocarditis shows inflammatory infiltrate but no evidence of myocyte injury ${ }^{2}$.

To diagnose myocarditis, endomyocardial biopsy and histological examination should be performed ${ }^{3,4}$. Thus, a pathologist is an important member of the multidisciplinary approach to the diagnosis and management of such cases ${ }^{5}$. The role of the pathologist is to establish a histopathologic diagnosis of myocarditis using the Dallas criteria; to exclude other morphological and clinical mimics of inflammatory myocardial disease, to classify the specific type of myocarditis (eg, lymphocytic, giant cell, hypersensitivity, toxic, infectious, sarcoidosis), and to preserve tissue for research purposes (e.g.: microbiologic, immunohistochemical, molecular $)^{6}$.

A large retrospective pediatric study revealed that myocarditis is the most common cause of sudden unexpected cardiac death in childhood, followed by hypoplastic left heart syndromes and dilated cardiomyopathy ${ }^{7}$. The major etiological agents of myocarditis are viral, bacterial, fungal, protozoal and parasitic microorganisms; toxins, hipersensitivity and immunologic syndromes (Churg-Strauss, inflammatory bowel disease, giant cell myocarditis, diabetes mellitus, sarcoidosis, systemic lupus erythematosus, thyrotoxicosis, Takayasu's arteritis, Wegener's granulomatosis) ${ }^{1}$. IGCM is a rare cause of arrhythmia, heart failure and death in children, of which the etiology is unknown ${ }^{8-10}$. The Giant Cell Myocarditis Study Group identified heart failure symptoms as the primary presentation in $75 \%$ of patients with giant cell myocarditis ${ }^{4}$. In about $20 \%$ of cases, myocarditis is associated with a number of immune diseases ${ }^{9,10}$. 


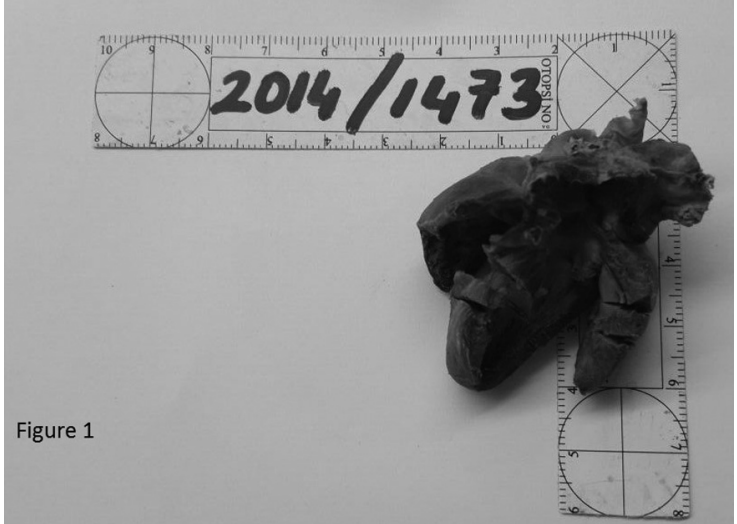

Fig. 1. On gross examination, the heart weighed $50 \mathrm{~g}$. The left ventricle wall was $1 \mathrm{~cm}$ and the right ventricle wall was $0.3 \mathrm{~cm}$ in thickness. Intracardiac anatomy was normal as were the origin and anatomy of the coronary arteries

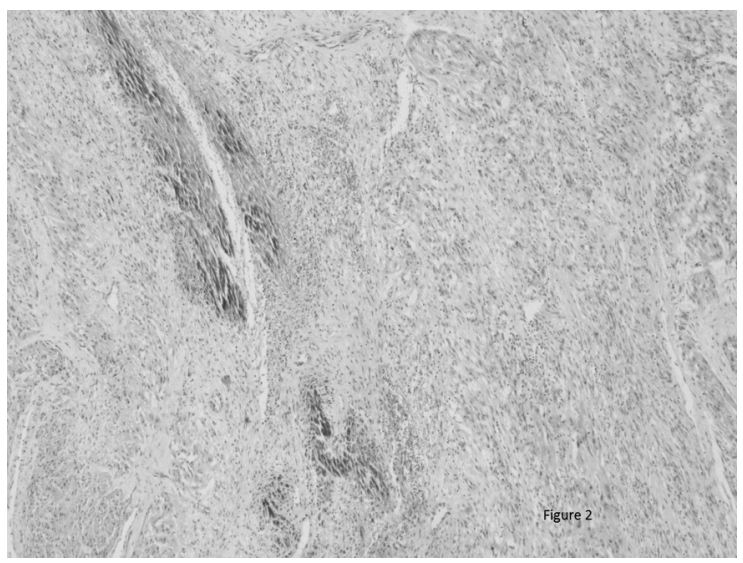

Fig. 2. Widespread and multifocal necrosis of myocytes was observed (H\&E, X100)

\section{Case Report}

In our case, a one-month-old baby boy died during breast-feeding without any diagnosed disease in advance. Parents stated that they did not notice any significant problem with the baby until the incident. They also report that they have been warned about cardiac arrhythmia by the family physician when they took the baby for routine control. Since they did not pay attention to the warning, no further diagnosis was made. He was the first child of the couple and when family history was enquired they mentioned no other example of similar condition. Additionally the mother had a problem-free pregnancy.

The autopsy was performed in the Forensic Sciences Institution of Turkey, Ankara Head Office. Tissue sampling from main organs was done by a pathologist. Light microscopic

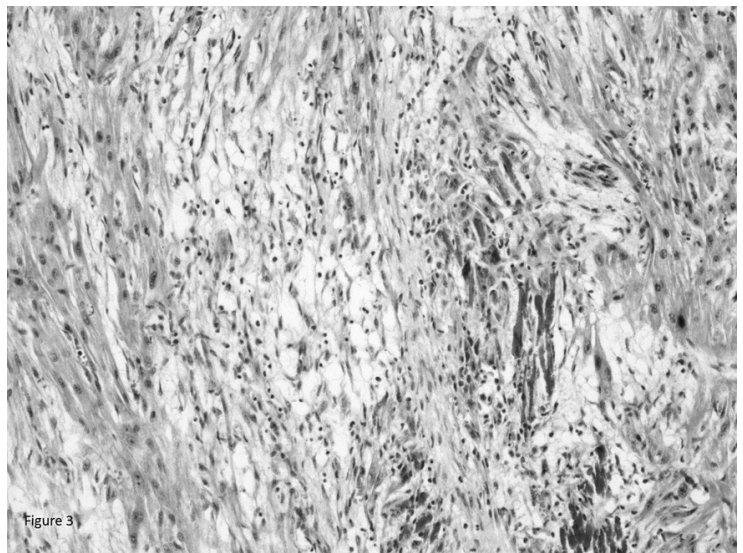

Fig. 3. Admixed with the inflammatory infiltrate were fibroblastic proliferation and multinucleated giant cells in the absence of sarcoid like granuloma (H\&E, X200)

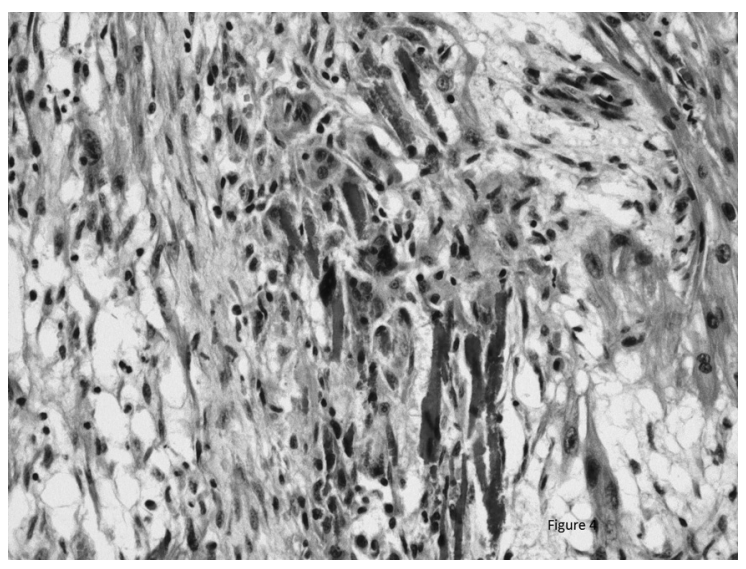

Fig. 4. Granulation tissue composed of mixed inflammatory infiltrate: lymphocytes, histiocytes scarce eosinophilic polymorhocytes and plasma cells. (H\&E, X400)

evaluation of the H\&E stained slides was performed after tissue processing. On gross examination, the heart weighed $50 \mathrm{~g}$. The left ventricle wall was $1 \mathrm{~cm}$ and the right ventricle wall was $0.3 \mathrm{~cm}$ in thickness. Intracardiac anatomy was normal as were the origin and anatomy of the coronary arteries (Fig. 1). Neither any gross pathology of the other organs, nor any postmortem toxic substance were detected. When H\&E stained cardiac tissue slides were examined by the pathologist, widespread and multifocal necrosis of myocytes was observed. Accompanying mixed inflammatory infiltrate, which is composed of lymphocytes, histiocytes, scarce eosinophilic polymorhocytes and plasma cells, was detected. Admixed with the inflammatory infiltrate were fibroblastic proliferation and multinucleated giant cells in the absence of sarcoid like granuloma (Figs. 2-4). 
Microscopic sections of the other internal organs revealed no pathology but congestion ${ }^{11}$.

\section{Discussion}

At the first step of the differential diagnosis, one should keep in mind considering neonatal myocardial infarction and overlap with myocarditis ${ }^{12}$.

The differential diagnosis of IGCM includes drug reactions and systemic diseases such as sarcoidosis, Wegener granulomatosis, foreign body reaction, hypersensitivity myocarditis, cardiac lymphoma, fungal myocarditis, tuberculosis and rheumatic carditis. The different clinical presentations and/or histologic findings of these disorders enable pathologists to make a differential diagnosis ${ }^{13}$. Endomyocardial histolopathological evaluation is still the gold standard for making the diagnosis of cardiac disease $^{1,10}$. It establishes to diagnose the disorders of heart such as cardiomyopathies, myocarditis, infiltrative lesions, arrhythmias and drug toxicities ${ }^{10}$. But myocarditis can affect only focal areas of myocardium, which is the most crucial handicap of histopathological diagnosis. According to a Mayo Clinic study of endomyocardial samples obtained post mortem from the hearts of patients who died of myocarditis, they reported a false negative rate of $37 \%$ for the right ventricle ${ }^{14}$. So it is recommended that to reduce sampling error, at least 4 to 5 pieces from each specimen must be obtained ${ }^{6}$.

If there is any suspicion for infection, special stains for microorganisms should be performed 13 .

The etiology of giant cell myocarditis is not known, but mostly predicted to be autoimmune 3,4,9-11,13. Experimental studies suggest that genetic factors may play a major role in tendency to disease ${ }^{13}$. IGCM is usually a lethal disorder that generally affects young otherwise healthy people ${ }^{13}$. Unlike lymphocytic myocarditis, which generally has good prognosis, IGCM usually results in death or heart transplantation. The overall rate of IGCM is equal for males and females. Compared to males, IGCM in females may be more strongly associated with autoimmune disease in other organs ${ }^{9}$.

Our case is presented in order to highlight that IGCM is a rare and highly lethal disease which can only be diagnosed by microscopical examination. The diagnosis of giant cell myocarditis should be considered for all patients with subacute heart failure of unknown cause. Infants, as we present in our case, can also be affected by myocarditis, which is usually thought to be older children's disease. Some cases of sudden unexpected death in children can be caused by this entity.

\section{REFERENCES}

1. Magnani JW, Dec GW. Myocarditis: current trends in diagnosis and treatment. Circulation 2006; 113:876890.

2. Aretz HT, Billingham ME, Edwards WD, et al. Myocarditis: a histologic definition and classification. Am J Cardiovasc Pathol 1986; 1: 3-14.

3. Kodama M, Zhang S, Hanawa H, Shibata A Immunohistochemical characterization of infiltrating mononuclear cells in the rat heart with experimental autoimmune giant cell myocarditis. Clin Exp Immunol 1992; 90: 330-335.

4. Cooper LT Jr, Berry GJ, Shabetai R. Idiopathic giant-cell myocarditis-natural history and treatment. Multicenter Giant Cell Myocarditis Study Group Investigators. N Engl J Med 1997; 336: 1860-1866.

5. Billingham M. Acute myocarditis: a diagnostic dilemma Br Heart J 1987; 58: 6-8.

6. Berry GJ, Atkins KA. Pathology of Human Myocarditis. Myocarditis, From Bench to Bedside. Totowa, NJ: Humana press, 2003; 14: 325-371.

7. Ilina MV, Kepron CA, Taylor GP, Perrin DG, Kanto PF, Somers GR. Undiagnosed heart disease leading to sudden unexpected death in childhood: a retrospective study. Pediatrics 2011; 128: e513-e520.

8. Davies MJ, Pomerance A, Teare RD. Idiopathic giant cell myocarditis-a distinctive clinicopathological entity. Br Heart J 1975; 37: 192-195.

9. Cooper LT. Giant cell myocarditis in children. Prog Pediatr Cardiol 2007; 24: 47-49.

10. Cunningham KS, Veinot JP, Butany J. An approach to endomyocardial biopsy interpretation. J Clin Pathol 2006; 59: 121-129.

11. Akça Kaya E, Pakiş I, Özbay M, Büyük Y, Küçük C. Dev hücreli miyokardite bağlı ani ölüm. Acıbadem Üniversitesi Sağllk Bilimleri Dergisi 2010; 1: 235-237.

12. de Vetten L, Bergman KA, Elzenga NJ, van Melle JP, Timmer A, Bartelds B. Neonatal myocardial infarction or myocarditis?. Pediatr Cardiol 2011; 32: 492-497.

13. Cooper LT. Idiopathic Giant Cell Myocarditis. In: Cooper LT (ed). Myocarditis From Bench to Bedside (2 ${ }^{\text {nd }}$ ed). Vol. 17. New Jersey: Humana press, 2003: 405-420.

14. Hauck AJ, Kearney DL, Edwards WD. Evaluation of postmortem endomyocardial biopsy specimens from 38 patients with lymphocytic myocarditis: implications for role of sampling error. Mayo Clin Proc 1989; 64: $1235-1245$. 